This next paper in Polar Research's series of not-formallyreviewed biographical/historical articles comes to us from anthropologist Pete Capelotti, who specializes in the history of exploration. In 1993, he conducted archaeological research on the base camps of the Andrée and Wellman polar balloon expeditions at Virgohamna, Danskøya, Svalbard. In this account of Walter Wellman's attempt to reach the North Pole from Franz Josef Land in 1898-99, he examines the lone success in that effort, when one American and four Norwegians discovered and explored the last large island in the archipelago.

\title{
E. B. Baldwin and the American-Norwegian discovery and exploration of Graham Bell Island, 1899
}

\section{P. J. Capelotti}

Division of Social and Behavioral Sciences, Penn State University, Abington College, Abington, PA 09001, USA, pjc12@psu.edu.

On 16 February 1899, after a fall and winter of discontent in Franz Josef Land, the American journalist Walter Wellman wrote to his second-in-command, Evelyn Briggs Baldwin, that Baldwin would not be a part of Wellman's upcoming attempt to reach the North Pole. This contradicted Wellman's promise-made during the previous summer upon the arrival of the expedition to Hall Island in the Franz Josef Land archipelago - that Baldwin would not only participate in his so-called "Polar Dash" but would even lead it. Baldwin's inept leadership of the five Norwegians under his command in the advance party, along with his continuous stream of demoralized missives written to Wellman at the Hall Island base camp, soured Wellman on Baldwin's abilities. Wellman had instructed Baldwin in August 1898 to establish a forward camp as far as $82^{\circ} \mathrm{N}$ for a planned spring polar attempt. But slow progress over ice-filled straits in a canvas canoe prevented Baldwin from advancing farther than Cape Heller on Wilczek Land, at only $80^{\circ} 45^{\prime} \mathrm{N}$.

When Wellman headed north on 17 February 1899, he did so without Baldwin nor with any of the other Americans. On 27 February, Wellman and three of the Norwegians on his expedition formed a "Polar Dash" team that trudged to the advance hut Baldwin and the Norwegians under his command had constructed at Cape Heller the previous fall. There Wellman's team discovered that one of 
the Norwegians left in charge of the site, Bernt Bentsen, had died over the winter (Wellman 1899a: 499, 1911: 76-83; Baldwin 2004:19-20). With his typical overstatement, Wellman described the incident as "one of the most remarkable tragedies known to the history of Arctic exploration" (Wellman 1899a: 498-499).

When Wellman fractured his leg and returned in defeat from his brief sledge trip north, he apparently forgot his earlier admonition regarding the keeping of journals. He had warned his team that any journals were to be turned over to him at the conclusion of the expedition. But Baldwin's extended description of the 1898 advance work was found amongst Baldwin's papers at the Library of

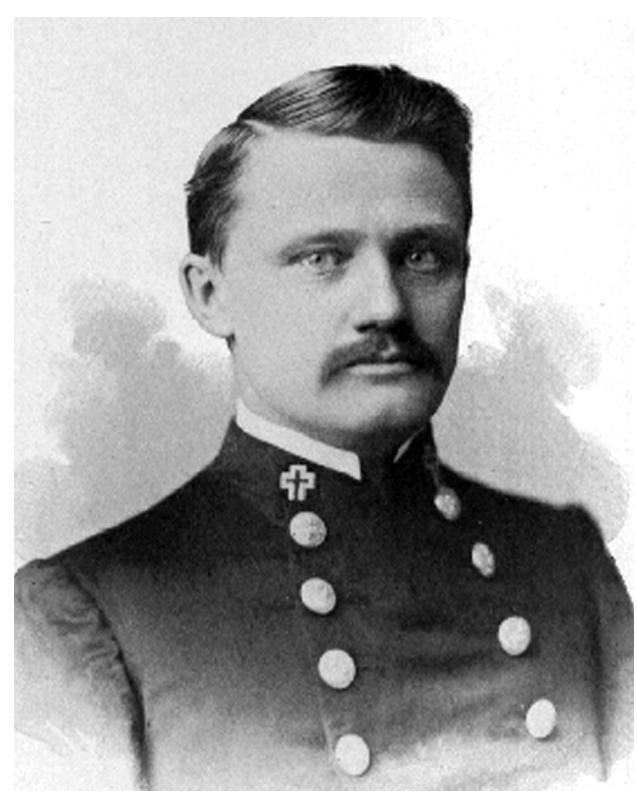

Evelyn Briggs Baldwin, from his book, The search for the North Pole (1896). Congress in Washington, D. C. It appeared in published form more than a century after the expedition's unsuccessful conclusion (Baldwin 2004).

In an apparent attempt to salvage some good result from the expedition after his failed stab at the pole, the immobile Wellman sent Baldwin to explore the eastern coast of Wilczek Land in the spring of 1899. The previous fall, Baldwin thought he had seen new features in that direction. This brief sledge expedition would lead to the only significant geographic discoveries of the expedition, as Baldwin and the Norwegians Daniel Johansen, Emil Ellefsen, Olaf Ellefsen and Paul Bjørvig located a large island Wellman later named for Alexander Graham Bell. Baldwin's field notes from this spring sledge expedition reveal the first glimpses of Graham Bell Island, the easternmost island in the Franz Josef Land archipelago.

\section{No place in the basket: Baldwin's early career}

Evelyn Briggs Baldwin was born in the American Midwest in 1862, first son of an itinerant teacher and Civil War quartermaster. Baldwin's father eventually settled the family on a Kansas farm so that his three "mischievous boys might escape the evil influences of town life" (Baldwin 1901a: 1).

Baldwin traveled widely as a post-graduate, first on a year-long tour of Europe which he financed by selling subscriptions to a monthly magazine he wrote, called Europe Afoot. Beginning as a pedestrian in Ireland, he learned to ride a bicycle in Glasgow and then proceeded "on the wheel" through Scotland, Wales, England, 
Belgium, France, Switzerland, Germany and Holland. Two thousand subscribers followed his adventures. He followed his European tour with one through the American West, and claimed to be the first to ride a bicycle through Yellowstone National Park, "compelled often to follow mere trails through the pine forests, and to wade streams, carrying the wheel on my back" (Baldwin 1901a:2-3). After five years of such travels, Baldwin went to work as an Assistant Observer for the US Weather Bureau.

It was as a meteorologist that Baldwin signed on to Robert Peary's second expedition to North Greenland. At Anniversary Lodge, on the shores of Bowdoin Bay, Baldwin kept notes on weather and aurora phenomena from 3 August 1893 to 1 August 1894. On his return from Greenland, Baldwin's description of Peary's efforts as a "partial failure...clearly owing to inadequate provisions and equipment" (Baldwin 1896:463) led to a permanent rift with Peary.

Immediately upon his return, Baldwin wrote to journalist Walter Wellman, himself just returned from his first polar expedition, a failed attempt to reach the North Pole from Svalbard (Wellman 1911:17-34; Alme 1998). This was apparently the first contact between the two. Wellman replied on that he was "glad to hear that you are still of the Arctic mind," but that a planned expedition for 1895 had to be put over to 1896, and in the event was not organized until 1898 (Wellman to Baldwin, 12 November 1894, Baldwin Papers).

With no American expedition to join and in an attempt to strike out on expeditions of his own, Baldwin published in 1896 The search for the North Pole, a 520-page history of Arctic exploration and fund-raising tract. Baldwin's purpose was to show how private and corporate sponsorship had led to geographic and natural resource discoveries redounding to the eternal fame of the sponsor. The next to last chapter of Baldwin's book was devoted to the just-announced Andrée polar balloon expedition, a voyage Baldwin now determined to join.

In the years that followed, Baldwin would tell numerous public versions of his attempt to reach Andrée's base camp and secure a place in the gondola of Andrée's balloon Örnen. In the Los Angeles Times of 24 March 1912, Baldwin told a reporter that "in 1897 I volunteered to accompany Andre [sic] in his balloon but arrived at the starting point two days after Andre and his two companions had departed for the North Pole never to be heard of again." In the San Francisco Examiner of 10 March 1911 he was much more direct: "...I was with the Spitzbergen balloon expedition in 1897." In the organization journal Masonic Standard of 3 March 1906, Baldwin dramatically arrived just after lift-off: "In 1897 I made the voyage to the Andree [sic] balloon station, as a volunteer to join Andree, in case his services could be utilized, but arrived too late, the balloon having sailed with the first southerly breeze.' In the boy's newspaper Grit of 7 July 1901, Baldwin arrived before lift-off, but found the balloon too small: "...in 1897 [Baldwin] barely escaped sharing the fate of Andree [sic]. Baldwin went to Spitzbergen, Norway, with the full intention 
of accompanying Andree, but when he arrived he found that the balloon was too small to carry a third passenger, so he was forced to abandon the trip which in all probability proved fatal to Andree and his companion[s] in aeronautic Arctic exploration."

In a newspaper interview in the New Orleans Daily Picayune of 31 January 1900, Baldwin chose the 'no room in the basket' version. "My second trip to the arctics, in 1897, was for the purpose of accompanying Mr. Andree [sic], if possible... I was disappointed in not having been able to accompany Mr. Andree, as there was not room enough in the basket for me... I enjoyed the personal acquaintance of Captain [Ernst] Andree (the explorer's brother), who was an ex-officer in the Swedish navy, and whom I had met in Sweden. With Mr. Andree I frequently corresponded during his preparation of the balloon, and I had volunteered to go with him. Although before reaching Spitzbergen I had been informed that there would be no room in the basket for one more person, yet I kept on my journey, hoping that at the last moment, through some fortuitous occurrence, there might be room for a substitute."

As the collection of his private papers reveals, Baldwin's "frequent" correspondence with Andrée amounted to two terse replies from the Swede. Andrée wrote that he was glad to have Baldwin's confidence in the balloon idea, "but as all the places in the basket are occupied I can on no account give you one" (Andrée to Baldwin, 20 December 1896, Baldwin Papers). Apparently unconvinced, Baldwin wrote again in the spring of 1897, and again Andrée rebuffed him, this time in one line: "Dear Sir! I am sorry to say that there is no place for you in the basket. Yours truly, S. A. Andrée" (Andrée to Baldwin, 13 April 1897, Baldwin Papers).

Baldwin was still not dissuaded. In the summer of 1897, he made his second journey to the Arctic, this time to Svalbard on board the tourist steamer Lofoten, captained by Otto N. K. Sverdrup, captain of the Fram on Fridtjof Nansen's threeyear polar drift from 1893 to 1896. In one of his versions, Baldwin had Lofoten arriving at Danskøya (Danes Island) two days after the departure of Andrée in his balloon. However, receipts in his papers show that Baldwin was still in Christiania (Oslo) in mid-July, purchasing photographs of Nansen's 1896 homecoming for use in his freelance articles (Receipt, Worm-Petersen Fotograf, 15 July 1897, Baldwin Papers). When Örnen came down on the ice on 14 July 1897, Baldwin was paying his bill of seven kroner six øre at the Grand Hotel (Receipt, 14 July 1897, Baldwin Papers). Whatever the truth of his 1897 Norwegian sojourn, he had missed his chance to fly toward the North Pole. The idea of aerial polar exploration would fascinate Baldwin for the rest of his life.

It is clear enough that Baldwin did make a journey to Svalbard later that summer, because he was later able to recoup part of his expenses by selling some botanical specimens to an American university. He was likewise not shy about trying to earn a living from the efforts of his Swedish polar colleague. In a macabre incident in 
the winter of 1897, Baldwin attempted to sell the rights to an American lecture tour by Andrée for one thousand dollars. Aside from the fact that he did not own such rights, Baldwin was unwittingly arranging a tour for someone who at that moment had been dead for about four months. The lecture promoter seemed well aware of this possibility. "I can make as big a fortune for Andree [sic] as any man ever made in this world, at this business, if he turns up" (Pond to Baldwin, 9 February 1898, Baldwin Papers, italics mine).

Baldwin would later use this 'inflated' experience with Andrée in his successful effort to convince American business magnate William Zeigler to finance a polar expedition with Baldwin as leader. He wrote that Andrée was "only sorry that he not room enough in the basket of the balloon for me" (Baldwin 1901a:4), a rather generous interpretation.

Baldwin then favourably compared his experience with that of Andrée. He wrote that he possessed experience in ice-field and sledge travel which the Swede did not, and that if Andrée "as a young man [Andrée was 43] could secure sufficient funds for an expedition, [then] I would likewise be successful." When the harsh economy of 1896-97 forestalled his fund-raising, Baldwin joined Walter Wellman's 1898 expedition to Franz Josef Land.

\section{To the farthest outpost of the American frontier: Baldwin at Fort McKinley}

In the summer of 1898, with E. B. Baldwin as his second-in-command and meteorologist, Walter Wellman chartered the Norwegian ice-steamer Frithjof and launched his polar expedition to Franz Josef Land, intent on using the archipelago as a base camp from which to sledge to the North Pole. Wellman and Baldwin were accompanied by two other Americans, Quirof Harlan and Edward Hofma, and five Norwegians, Paul Bjørvig, Bernt Bentsen, Daniel Johansen, Emil Ellefsen and Olaf Ellefsen. The Norwegians signed on for what Wellman promised them would be a "very troublesome" journey (see Anonymous n.d.).

Before establishing a base camp at Cape Tegetthoff on Hall Island, Wellman and Baldwin engaged in a vain search for the missing Andrée and his crew (Baldwin 2004:9-10). At Cape Tegetthoff, Wellman's base camp was at $80^{\circ} 05^{\prime} \mathrm{N}$, approximately $850 \mathrm{~km}$ from the pole. Using materials taken from the base of Frederick Jackson's expedition (1894-97) at Cape Flora, on Northbrook Island, Wellman's crew built the expedition's headquarters. They dubbed it "Harmsworth House," apparently with the permission of the British newspaper publisher Alfred C. Harmsworth, who had sponsored Jackson's expedition.

Wellman ordered Baldwin to establish an outpost as far north as possible, one that would serve as a jumping off point for Wellman's planned bid for the pole in the spring of 1899. This sector of the archipelago was only dimly known since Payer's 
charting of the southern area of Austria Sound in the 1870s and Nansen's brief encounter with the islands in the north-east of the archipelago in August 1895.

Baldwin was to build a hut as far as $82^{\circ} \mathrm{N}$ and stock it with a ton and a half of dried polar bear and walrus meat and other provisions and supplies. Armed with an extended set of nebulous instructions from Wellman, Baldwin's advance party left Harmsworth House on 5 August. The party consisted of Baldwin and the Norwegians Paul Bjørvig, Bernt Bentsen and Emil Ellefsen.

To reach $82^{\circ} \mathrm{N}$, build a winter hut and dash back to Harmsworth House before the onset of winter, Baldwin's party would have to make at least $6.4 \mathrm{~km}$ a day. On the days when weather and ice allowed travel, they crawled ahead less than half that distance. Crossing dangerously broken floes in a canvas canoe, struggling along shorelines strewn with glacial debris, the team moved north for a month. On 20 September, a month and a half after leaving Harmsworth House, Baldwin reached

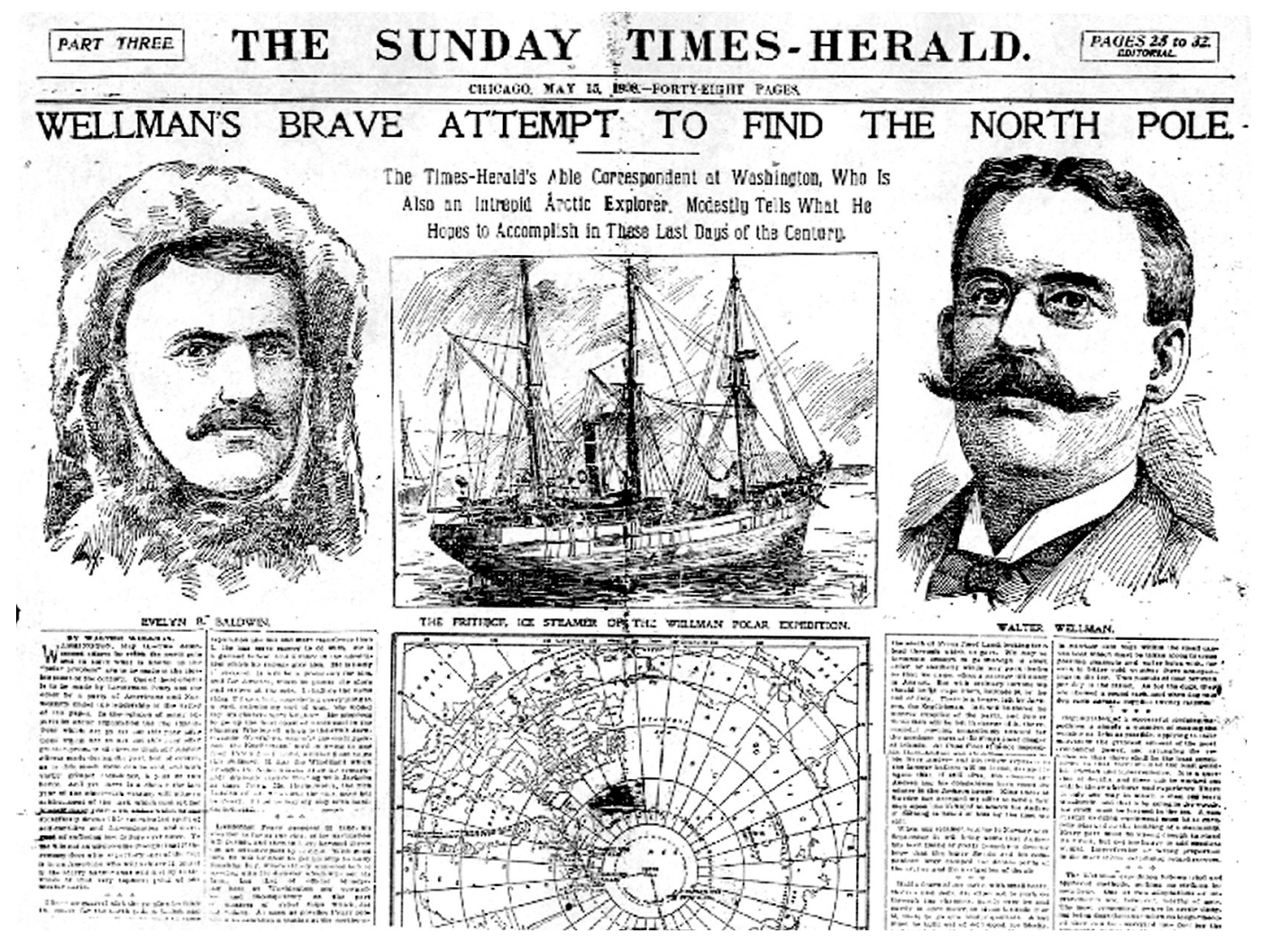

Newspaper article on the Wellman expedition to Franz Josef Land from The Sunday Times-Herald, Chicago, 15 May 1898. The subtitle reads: "The Times-Herald's able correspondent at Washington, who is also an intrepid Arctic explorer, modestly tells what he hopes to accomplish in these last days of the century". Baldwin is pictured on the left, Wellman on the right. (Courtesy Evelyn B. Baldwin, Scrapbooks, 1898-1929, Western Historical Manuscript Collection, Columbia, MO.) 
Cape Heller and stopped there to begin construction of the winter hut.

To William Ziegler, Baldwin later wrote that he "returned [to Harmsworth House] having successfully accomplished the object for which I had been sent out. This outpost I named 'Ft. McKinley'.' This was another considerable exaggeration, since the "fort" was located well short of even $81^{\circ} \mathrm{N}$, and more than $150 \mathrm{~km}$ south of where Wellman intended it. In addition to the failure to establish a far northern depot, Baldwin's lack of leadership skills poisoned his relationships with his Norwegian comrades.

Paul Bjørvig kept a diary of his experiences sledging with Baldwin, and polar historian Susan Barr has studied the diary in its original Norwegian. She writes that Bjørvig "complained often in his diary of Baldwin, who apparently did very little other than to order the Norwegians around like slave labour. He also kept the Norwegians on a diet of walrus and bear meat while he secretly ate other supplies they had with them" (Barr 1995: 78). Baldwin's own journal seems to confirm these observations (Baldwin 2004: 16-18).

On 6 October, as Bjørvig complained about the lack of a tent for the spring sledge trip, Baldwin cut the party's tobacco ration. Two days later, Baldwin reduced the biscuit ration to two per day and began to withhold sugar from the men. With an incipient mutiny on his hands, Baldwin selected Bjørvig and Bernt Bentsen from the advance party to remain behind to guard the fort's supplies over the winter. Baldwin and the rest of the advance team were back at Harmsworth House at the end of October.

During the late fall and into the winter, Baldwin had carried out recordings of temperature, air pressure and wind speed. With the onset of winter, he added to these a study of the aurora borealis (Baldwin 1899a, 1901b). These latter observations tended to be almost poetical rather than strictly scientific, as in his description for the evening of 3 March 1899, when he found the aurora "an intense display of coronal type, covering the heavens from the belt of Orion, in the south southwest, to the lower limbs of Hercules, in the north, and from Virgo, in the east, to Pegasus and Pisces, in the west. Rapid movement of streamers and curtains from west to east and from south to north. Delicate tinting of the display in all its parts, but particularly striking along the edges of the enveloping or outer curtains" (Baldwin 1899a: 36).

The winter at Harmsworth House was apparently a tense one, despite Wellman's claim that "not a word of discord between Yankees and Norsemen marred the novel experience" (Wellman 1899a: 498). A disagreement between Baldwin and the Norwegians over a missing blanket was resolved only after a formal exchange of memoranda between Baldwin and Wellman. Eventually, Wellman reduced Baldwin's status to that of a co-equal if not a subordinate to another expedition member, Dr Edward Hofma. In the event Wellman failed to return from his bid for the North Pole, he had entrusted to Hofma all papers and photographs generated by 
Julius Payer's chart of Austria Sound, showing his conception of a continuous Wilczek Land and a large Zichy Land (and the non-existent King Oscar Land and Petermann Land). (From New lands within the Arctic Circle, 1876.) While exploring the North-east Passage in 1872-74, Karl Weyprecht's and Payer's expedition found Franz Josef Land. They named the archipelago after the Austro-Hungarian emperor.

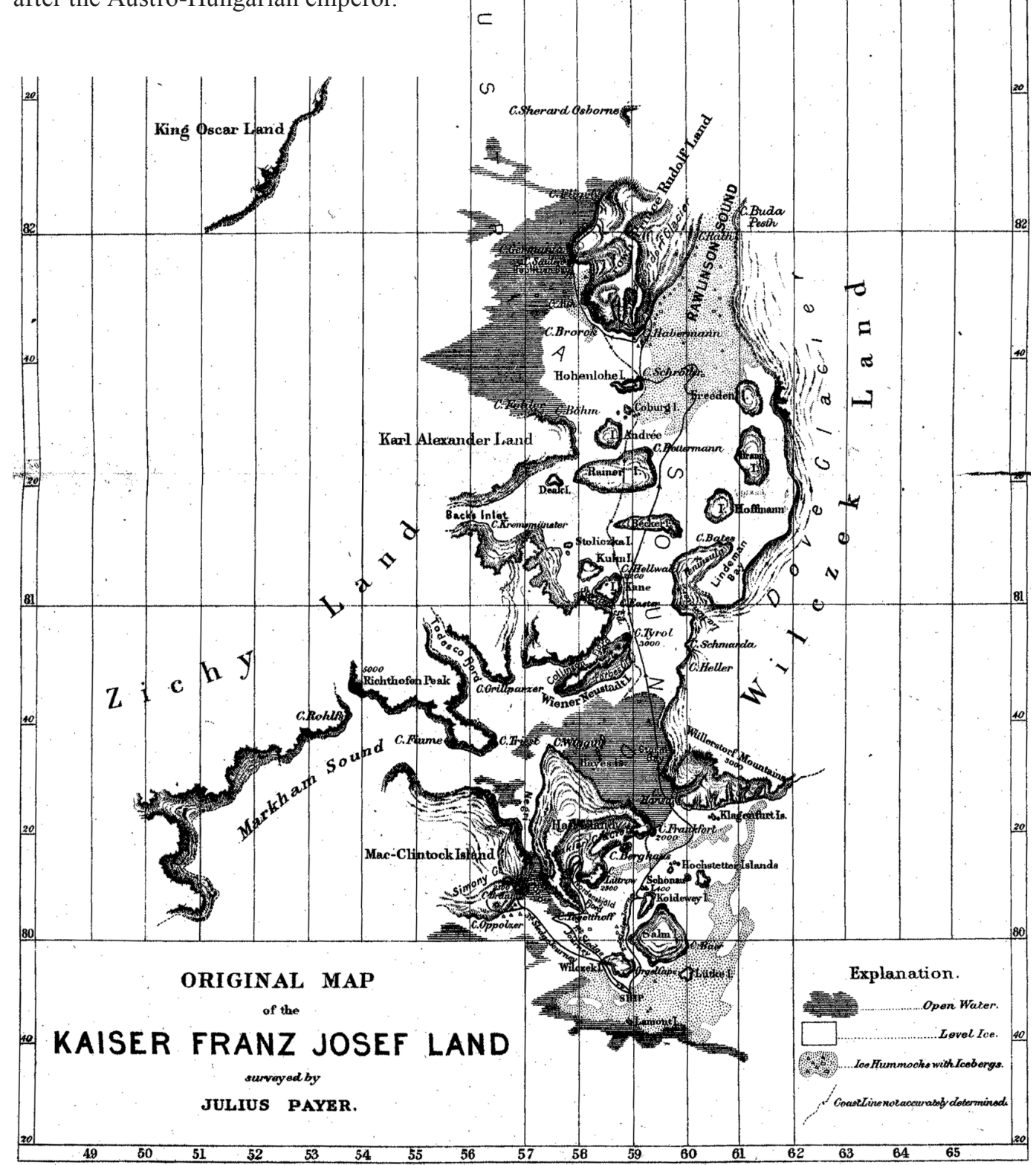


the expedition, and specifically ordered Baldwin to turn over his personal journal to Hofma before the surviving expedition members reached Norway on the voyage home (Baldwin 2004: 160).

Wellman and the Norwegians who made up his "Polar Dash" team-the Americans were all ill or, like Baldwin, had been demoted - finally reached the advance hut on 27 February. There they discovered that Bentsen had died two months earlier, and that Bjørvig had preserved the corpse in a sleeping bag. After the polar party buried Bentsen, they continued north for three weeks and another one $100 \mathrm{~km}$. Wellman slipped on the ice east of Rudolph Island and the expedition was forced to retreat, not before he imagined seeing four non-existent islands to the north-east which he named for "well-known American scientific and public men who had befriended the expedition" (Wellman 1899a: 503), including Secretary of State John Milton Hay (1838-1905) and President of the American Museum of Natural History Morris Ketchum Jesup (1830-1908). In his memoirs, Wellman reduced his error to only two islands, named after "two most valued friends, Ben T. Cable and Tom Johnson", with the admission that the Duke of the Abruzzi's expedition that arrived in Franz Josef Land just after Wellman's "found that what I had taken for two islands must have been only ice hummocks" (Wellman 1911: 117).

After Wellman had been carried back to Harmsworth House by the Norwegians, who were "as brave as lions and as tender as women" (Wellman 1899a:500), he

Wellman's chart of Franz Josef Land, showing the newly-discovered Graham Bell Island, along with Wellman's non-existent Hay, Jesup, Johnson and Cable islands to the north. (From Wellman 1899a.)

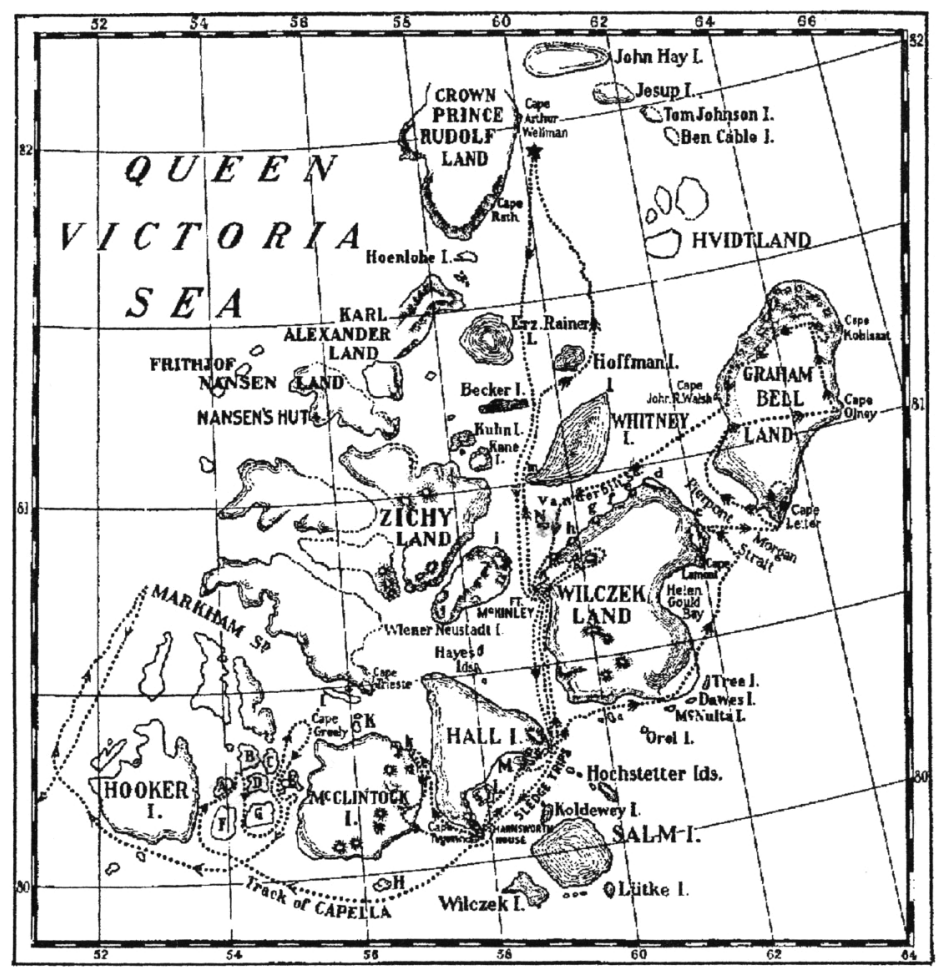


instructed Baldwin to explore the eastern coast of Wilczek Land in search of more new features for Wellman to name. This month-long sledge expedition led to the only significant geographic discoveries of the expedition, as Baldwin located a large (and real) island, which Wellman later named for inventor and National Geographic Society president Alexander Graham Bell (1847-1922). Although Wellman repeatedly warned Baldwin to mind Wellman's priority to name any feature discovered during the expedition to the north and east of Wilczek Land, Baldwin later penciled in the name of his father, Elias Baldwin, on the northern tip of Graham Bell Island.

\section{Sledging with Norwegians: Baldwin crosses Helen Gould Bay}

On Wednesday, 26 April 1899, Baldwin left Harmsworth House with a party of four Norwegians including Daniel Johansen, Emil Ellefsen, Olaf Ellefsen and Paul Bjørvig after his harrowing wintering at Fort McKinley. Wellman himself was bedridden from his leg injury, while the other two Americans never left the base camp during the whole of the expedition. Wellman later wrote that Dr Hofma, "medical officer and naturalist of the expedition, has a most interesting report concerning the fauna and flora of [Franz Josef Land]" and that Mr Harlan had also studied the aurora and "the physical conditions of Franz Josef Land" and that Wellman planned to publish these results "in proper form and place as soon as possible" (Wellman 1899a:492). Given their self-imposed confinement on Hall Island, the reports of Harlan and Hofma would have been limited in scope; in the end neither work was ever published.

For Baldwin, the spring sledge expedition "upon the unexplored east coast of this famous archipelago" was the chance to redeem an otherwise failed expedition. In his unpublished journal, he wrote that it would be "at least a partial compensation for my bitter disappointment at not having been able to accompany the Polar dash party" (Baldwin 1899b: 1).

For much of the first three days, the party was snowbound $8 \mathrm{~km}$ from Cape Frankfurt, the eastern tip of Hall Island and the crossing point to Wilczek Land. Temperatures hovered between -20 and $-25^{\circ} \mathrm{C}$. On Saturday, 29 April, they reached Cape Frankfurt and crossed ice-filled Austria Sound to Cape Hansa, at the south-west corner of Wilczek Land. After covering $22.5 \mathrm{~km}$, they made camp that evening north of a group of islets that Payer and Weyprecht, leaders of the Austro-Hungarian expedition of 1872-74, had named the Klagenfurt Islands (Payer 1876, II: xvi-xvii) and beyond which no one had yet ventured. Baldwin felt himself "upon [the] verge of discoveries" (Baldwin 1899b:2).

On Sunday, 30 April, the march continued along the southern coast of Wilczek Land, past two basaltic cliffs and interior mountains separated by glaciers, until the team reached Cape Hofer, on the south-east corner of Wilczek Land. There, 
Baldwin's sledge journey to Graham Bell Island, spring, 1899.

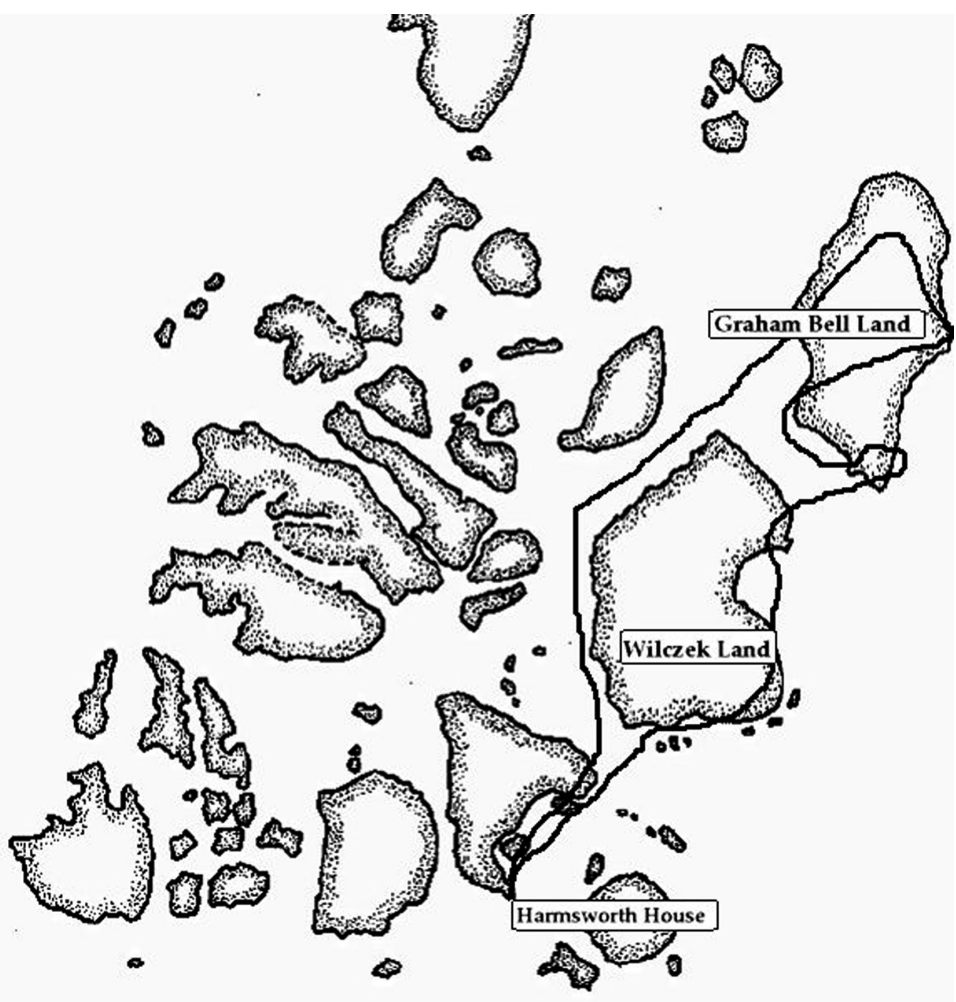

Baldwin spotted three islands to the south-east, which were later named McNulta, Dawes and Tree. With Emil Ellefsen he ascended the cape to take a round of bearings, shattering the thermometer in the process. Sliding back down the snowcovered slope, Baldwin recorded that he nearly broke his right arm and Ellefsen his back. In camp, the Norwegians shot a bear and the following morning breakfasted on its kidneys and heart.

Once the sledges were re-stowed, the party continued on for $3.7 \mathrm{~km}$, then after lunch north for $8.7 \mathrm{~km}$. They then set up camp near a large berg, "in a large bay never before seen by man" (Baldwin 1901b:354-356). Following his instructions from Wellman, Baldwin named it "Bay A." This became Helen Gould Bay, after the multimillionaire heiress daughter (1868-1938) of the notorious robber baron Jay Gould. Baldwin later wrote that it was "one of the most picturesque localities in these regions. In it I counted nearly sixty large icebergs, forming now a great white ice-locked fleet, the majority of which had perhaps been launched from the precipitous glacial wall forming the southern, western and northwestern sides of the bay, the northern boundary of which is formed by a basaltic cape" (Baldwin 1901b: 354), which was later named Cape Lamont.

On 2 May, the team crossed $8.5 \mathrm{~km}$ of twisted ice in Helen Gould Bay toward 
what Baldwin temporarily named Cape " $C$," later Cape Lamont, where they camped that night. Despite his glacier glasses, Baldwin began to suffer painfully from snow blindness. The following day, Baldwin and Olaf Ellefsen ascended the northern slope of the cape to an altitude of $317 \mathrm{~m}$. The very steep terrain made getting to the top, which they estimated at $518 \mathrm{~m}$, impossible, but they saw what appeared to be a large fjord or sound extending northward.

On the march the following morning, Baldwin observed a rocky cape, later named Cape Elkins, about $16 \mathrm{~km}$ north of Cape Lamont. At the same time, he noted a glacial slope on the eastern side of the sound. For the first time, he began to believe that what he was now crossing was not a sound but a strait. And indeed this proved to be a waterway that separated Wilczek Land from what Baldwin now realized was a new and large island. Wellman later named this strait after John Pierpont Morgan (1837-1913), one of the wealthiest bankers in the world.

Baldwin and his men reached the cape on the opposite shore on the evening of 4 May. While the Norwegians set up camp for the night, Baldwin walked toward the east, to try and find a passage northwards along the coast of this new shore. "But I had never before seen such a chaos of broken-up ice - the vast floes and pans being screwed together in a most frightful manner, as far as the eye could see in either an eastern or northeasterly direction" (Baldwin 1901b:355). He returned to camp, a location later named Cape Leiter. It was the southern point of the island Wellman later named Graham Bell Land.

\section{The American-Norwegian discovery and exploration of Graham Bell Island}

On Friday, 5 May 1899, OlafEllefsen called all hands for breakfast at 08:00. Baldwin wrote in his field notes: "9:40 start with Emil and Daniel, ascend the new land and is as I surmise island, $900 \mathrm{ft} .$. Bright sunshine and islands Nos. 1, 2 and 3 to se" (Baldwin 1899b: 6). But he almost certainly means "sw" here, as the islands off the south-east coast of Wilczek Land (McNulta, Dawes and Tree) would now appear in the south-west from his vantage point, from where he could also see Cape Hofer. About $1.5 \mathrm{~km}$ north-east from camp they encountered a granite knob, from which they could see the new coast trending off to the north-east, "a succession of small bights and intervening ice and snow-covered tongues of land" (Baldwin 1899b: 6). Noontime observations put their position at $80^{\circ} 38^{\prime} 23^{\prime \prime} \mathrm{N}, 62^{\circ} 38^{\prime} 30^{\prime \prime} \mathrm{E}$.

Baldwin traveled about $9.5 \mathrm{~km}$ along the coast, and watched as two or three guillemots flew overhead from the east. The eastern side of the island was impassable, rough ice at the bottom of a steep, $274 \mathrm{~m}$ cliff. With his way hopelessly blocked in that direction, Baldwin turned the party west, and began a $10.2 \mathrm{~km}$ trip over smooth ice back toward the strait. They camped on the night of 5 May on the south-western bend of Graham Bell Island, across from Cape "D," which later 
became Cape Vilas.

Baldwin estimated Cape "D" to be about $9.5-11 \mathrm{~km}$ away, and thought he might have seen this point the previous October while wandering in the vicinity of Fort McKinley. Turning the corner of the island, the party now headed north-east, toward a low point on the western side of Graham Bell Island that became Cape John R. Walsh. Baldwin made camp soon after, intending to travel eastward across the island the next day.

On 7 May, they started due east, ascending for $6.4 \mathrm{~km}$ to an altitude of $152 \mathrm{~m}$, then descended for $2.4 \mathrm{~km}$, before a steep ascent to $329 \mathrm{~m}$ about $10.5 \mathrm{~km}$ from morning camp. The runners on their big sledge gave way and were repaired with skis. They could see a rocky ledge all along the north-east coast of the island. After marching for another $3.2 \mathrm{~km}$, they made camp just as a heavy storm began that would drop snow on them for the next 36 hours. They rode out the storm on several meals of polar bear cub stew. Baldwin, as he had done throughout the advance hut journey the previous fall, called to his Norwegians whenever domestic chores were required. "Called Olaf and we ate our breakfast-dinner...Called Daniel to make a cup of coffee for each man" (Baldwin 1899b: 8).

On the morning of 9 May, with wind still flapping the sides of the tent and his attempt to take photographs thwarted by a frozen camera, Baldwin broke camp and continued north-east $6.4 \mathrm{~km}$ into the bottom of a valley that extended north and south. They then bore east-south-east, until Baldwin wrote that at 15:45 they had reached the "extreme eastern point and summit of this island..., [a] windswept ice knob and evidently glacier faced on east side. Valley to $n$. and low flat ice-point extending a little further east...To east, no land, but great extent screw ice and much open water and heavy dark clouds overhead. Elevation of ice knob probably from 900 to 1,000 ft" (Baldwin 1899b: 8-9). They had reached the edge of both Graham Bell Island and the Franz Josef Land archipelago itself.

At this icy land's end, they turned north to attempt to define the northern reaches of the island. Baldwin described it as "rolling ice country" (Baldwin 1899b:9). Perhaps the stress of reaching the eastern extent of the island caught up with them all, for Baldwin wrote that they all had two lime juice tablets. As soon as they were in camp, the primus was started to melt drinking water, when a storm pinned them down for more than 40 hours. When the storm cleared on the afternoon of 11 May, Baldwin reluctantly ordered a march northward, anxious to locate the northern point of the island. One of the Norwegians sarcastically remarked that he "felt like going fifty or sixty miles [80-96 km] today" (Baldwin 1899b: 10).

They walked for what Baldwin estimated to be $13 \mathrm{~km}$, the odometer becoming disabled on the march, before a storm stopped them again. They disposed of dinner quickly and in good cheer, "notwithstanding that Olaf chanced to spill a part of the coffee, that Bjorvik's stockings were found to be frozen to his feet upon getting into the bag, that Emil was compelled patiently to wait nearly an hour for his muffler 
to thaw loose from his whiskers, that Daniel had the odometer to repair, or that I have this journal to write!" (Baldwin 1899b: 10). Late in the day of 12 May, the team moved northward and steadily downwards for another $6.4 \mathrm{~km}$, "when lo! dark lines, as of open water lanes or streaks of land lay just ahead. The downgrade, too, suddenly became steeper and I awaited the arrival of the sledges and ordered a halt pending a reconnaissance. With alpine rope about the body I pushed carefully forward the odometer another half mile [0.8 km]" (Baldwin 1899b: 12).

Baldwin found himself suddenly standing upon bare rock (about $85 \%$ of the total land area of the archipelago is glacier-covered [Lefauconnier \& Slupetzky 1995]). The following morning, when the weather cleared, the men beheld "a panorama of snow-clad peaks and ridges that lay stretched before and below our feet", trending away to the south on both sides. They had reached the northernmost projection of the island. No other islands could be seen to the north. After taking a series of bearings, Baldwin decided it was a prudent moment to begin his retreat. On Sunday morning, 14 May, the team began its movement southward, covering $24 \mathrm{~km}$ across a fogbound series of ice domes. The following day saw just over $22.5 \mathrm{~km}$ put behind them.

Before turning in, the team discussed whether another island existed to the west, one not marked on Payer's chart. Baldwin thought that perhaps Payer's "La

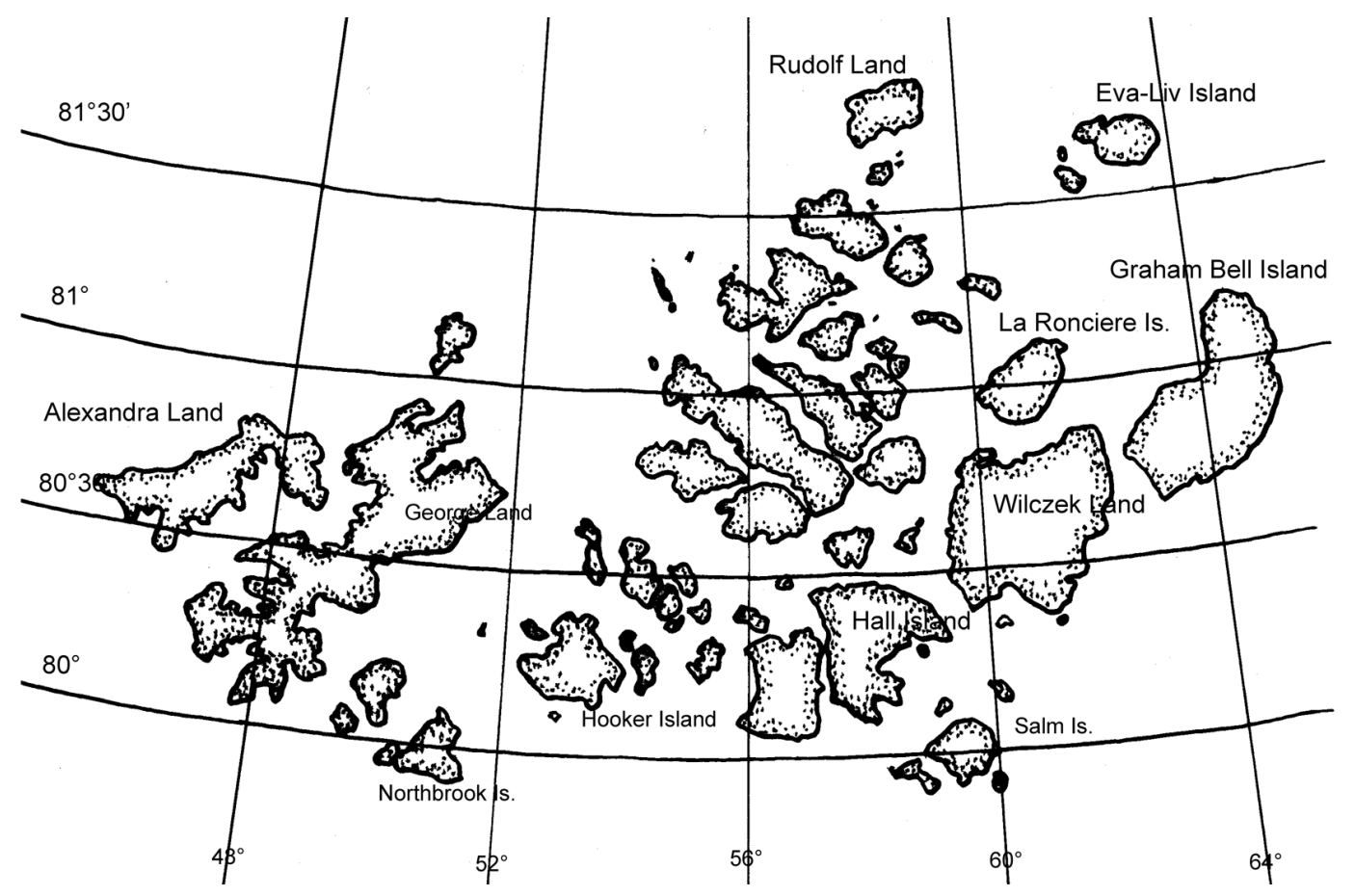

A modern chart of Franz Josef Land (modified from Barr 1995). 
Ronciere Peninsula" was instead an island. After a further $24 \mathrm{~km}$ on 16 May, they had reached the north-western coast of Wilczek Land and familiar territory from the sledge expedition of the previous fall. On 17 May, they returned to Fort McKinley. After a three-day stay at the "fort," Baldwin and his team spent nine days in their return to Harmsworth House.

\section{"Good American names": Baldwin and the obscurity of the polar failure}

The discovery of Graham Bell Island completed the geographic picture of the eastern limits of Franz Josef Land. As Wellman wrote, Julius Payer had located "an enormous glacier [Dove Glacier], capping a land of continental dimensions, extending northward from Wilczek Land" (Wellman 1899a:503). Nansen had taken the first slice out of this "continent" in 1896, and Baldwin had finished it off in 1899. He had also correctly surmised that Payer's "La Ronciere Peninsula," north of Cape Heller, was an island. Wellman tried to name it Whitney Island (most likely for another financier, William Collins Whitney (1841-1904), a former Secretary of the Navy (1885-89), but Payer's name ultimately won out and this island just north of Wilczek Land and west of Graham Bell Island became La Ronciere Island.

The expedition, Wellman later told a reporter, had been organized "to explore the unknown portions of Franz Josef Land; and to reach a more northern point than [anyone before]." This attempt to salvage something from what was in all regards a failure to reach the North Pole was not as transparent as his snub of the Norwegians who had carried his supplies north and then carried an injured Wellman himself south. "We are giving the islands, straits, and points good American names," Wellman told the press. Almost as if the Norwegians on his team had never existed, Wellman announced that "I don't favor the cooperation of nations in Arctic exploration" (Wellman 1899b).

For Baldwin, the sledge expedition to Graham Bell Island marked the high point of his polar career. Ahead lay the protracted fiasco of the 1901-02 Baldwin-Ziegler expedition, when Baldwin would return to Franz Josef Land with more money and supplies than he ever imagined, only to fritter these away in a remarkably pointless series of cache-laying exercises. It is likely that his apparent bitterness at discovering islands and capes, bays and glaciers in the spring of 1899 , only to have Wellman reserve the right to name them, led Baldwin to make a disastrous series of decisions during Baldwin-Ziegler. Rather than striking for the North Polewhat William Ziegler had paid for-Baldwin obsessed over locating new islands within the Franz Josef Land archipelago, recovering the message left by Nansen at his wintering hut on Jackson Island, and other personal quests such as following Andrée north in a balloon of his own.

Baldwin did manage from his base on Alger Island to fill several small hydrogen 
balloons and send them aloft carrying pleas southward for relief in June 1902. By one account he had an observation balloon capable of carrying an observer/ photographer aloft (Fawcett 1901:481-487). But after the expedition returned to Tromsø to resupply, he was bitterly denounced as a dangerous martinet by members of the expedition and quickly relieved of further command by William Ziegler (see, for example, Barnard Papers).

Baldwin spent the remaining three decades of his life regularly agitating on behalf of various schemes meant to give him a third chance at the Arctic. He first supported the claim to the North Pole of Dr Frederick Cook, even accompanying Cook on the lecture circuit. He abruptly turned on Cook in 1913, apparently reversing his two decades of contempt for Robert E. Peary (see Bryce 1997:560563). Baldwin repeatedly proposed polar drift voyages, expeditions by airship, even harnessing the electricity of the aurora borealis, which he claimed could light the world. But he never again found a receptive patron, and he died an obscure government clerk in Washington, D. C., in 1930.

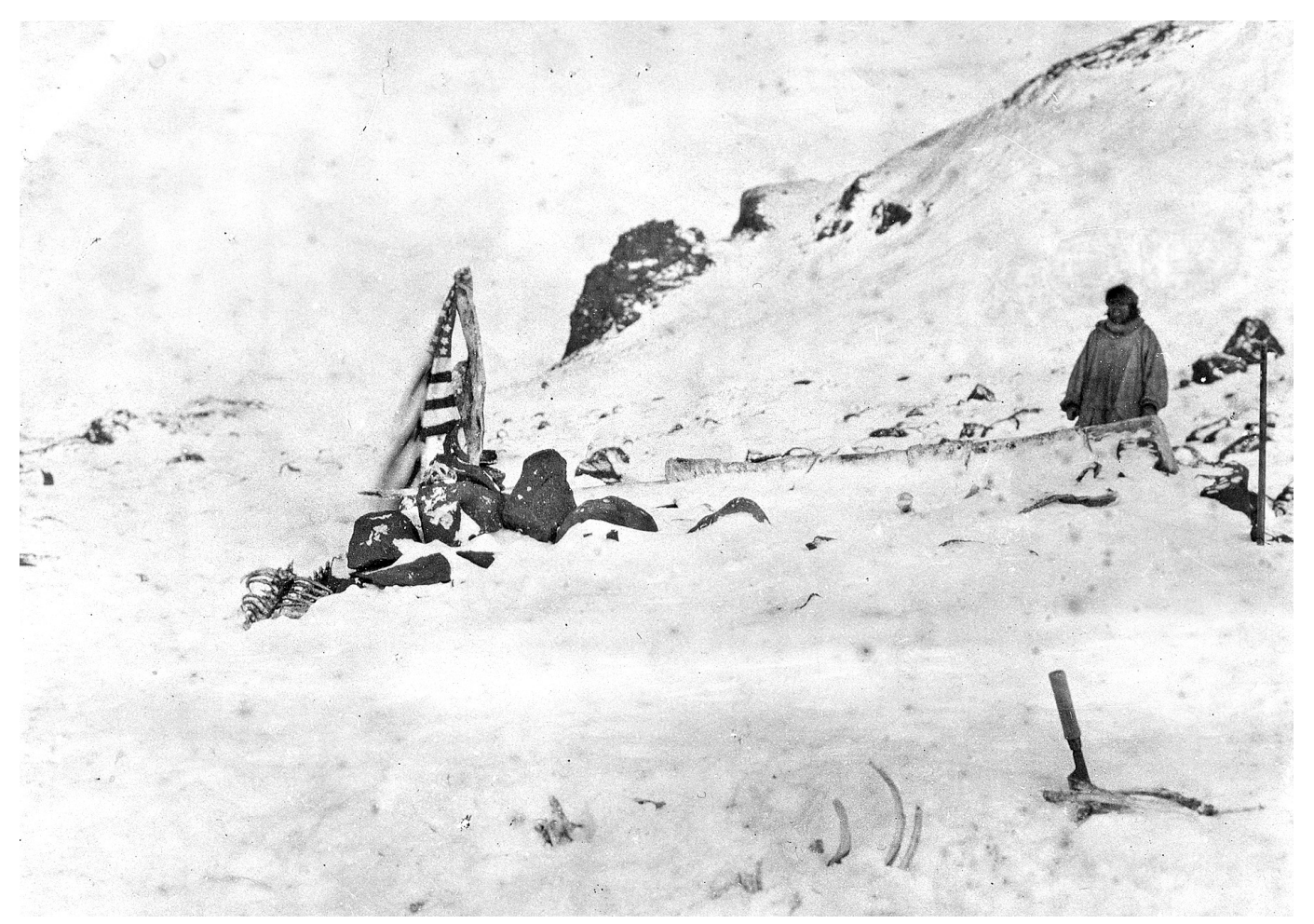

During the Baldwin-Zeigler expedition, Baldwin located the crude hut in which Fridtjof Nansen and Hjalmar Johansen overwintered at Cape Norvegia in 1895-96. He took the note Nansen had left behind, returning it to the Norwegian Legation in Washington, D. C. 30 years later. Note the skeletons (probably polar bear) in the foreground and just to the left of the hut (Photograph courtesy of the Norwegian Polar Institute Picture Library.) 
Acknowledgements.-The author wishes to thank Dr C. L. Devlin at Penn State University, Dr Susan Barr of Norway's Directorate for Cultural Heritage (Riksantikvaren), Dr Beau Riffenburgh and Ms Heather Lane of the Scott Polar Research Institute and Anders Larsson of the Gothenburg University Library.

\section{References}

Alme, H. H. 1998: Om Spitsbergen og den Wellmanske polarekspedisjon. (Spitsbergen and the Wellman Polar Expedition.) Skien, Norway: Vågemot miniforlag.

Anonymous n.d.: Conditions for engaging the men to the Wellman Polar Expedition. 1894/1898. Baldwin Papers. Manuscript Division, Library of Congress. Washington D.C.

Baldwin, E. B. 1896: The search for the North Pole. Chicago: Privately printed.

Baldwin, E. B. 1899a: Report on auroras. Baldwin Papers. Manuscript Division, Library of Congress. Washington, D.C.

Baldwin, E. B. 1899b: Discovery of Graham Bell Land. Baldwin Papers. Manuscript Division, Library of Congress. Washington, D. C.

Baldwin, E. B. 1901a: Short autobiographical sketch-Evelyn Briggs Baldwin, for William Ziegler, Esq. Baldwin Papers. Manuscript Division, Library of Congress. Washington, D. C.

Baldwin, E. B. 1901b: Meterological observations of the Second Wellman Expedition. In: Report of the Chief of the Weather Bureau, 1899-1900. Part VII. Pp. 354-356. Washington, D. C.: Government Printing Office.

Baldwin, E. B. 2004: The Franz Josef Land archipelago: E. B. journal of the Wellman Polar Expedition, 1898-1899. P. J. Capelotti (ed.). Jefferson, NC: McFarland \& Company, Inc.

Barnard, L. F. n.d.: MS 1514. Papers. Scott Polar Research Institute. (These papers were uncatalogued as of September 2005. From the family of one of the members of the Baldwin-Ziegler expedition to Franz Josefl Land in 1901-03, they present a highly critical view of Baldwin's leadership during that expedition.)

Barr, S. 1995: The history of Western activity in Franz Josef Land. In S. Barr (ed.): Franz Josef Land. Polarhåndbok 8. Pp. 59-106. Oslo: Norwegian Polar Institute.

Bryce, R. M. 1997: Cook \& Peary: the polar controversy, resolved. Mechanicsburg, PA: Stackpole.

Fawcett, W. 1901: By balloon to the North Pole. Metropolitan Magazine 14(4), 481-487.

Lefauconnier, B. \& Slupetzky, H. 1995: Glaciers. In S. Barr (ed.): Franz Josef Land. Polarhåndbok 8. Pp. 15-21. Oslo: Norwegian Polar Institute.

Payer, J. 1876: New lands within the Arctic Circle: narrative of the discoveries of the Austrian ship Tegetthoff in the years 1872-1874. 2 vols. London: MacMillan and Co.

Wellman, W. 1899a: The Wellman Polar Expedition. National Geographic 10(12): 481505.

Wellman, W. 1899b: Walter Wellman home. The Boston Globe. 9 October 1899.

Wellman, W. 1911: The aerial age. New York: A. R. Keller. 
